\title{
Ectomycorrhizal Fungi and Their Applications
}

\author{
Antonietta Mello, Elisa Zampieri, \\ and Raffaella Balestrini
}

\begin{abstract}
Ectomycorrhizal (ECM) fungi form association with relatively small number of plants that dominate boreal, temperate, Mediterranean, and some subtropical forest ecosystems. These plant species have been able to acquire metabolic capabilities through symbioses with ECM fungi, thus improving their mineral nutrition and growth in several ecological niches. Mycorrhizal fungi can also play several other important ecological roles, including the protection of plants from abiotic and biotic stresses. Several "targeted" metagenomic projects have been carried out, or are now in progress, in order to identify the fungal communities in soil, including ECM fungi, which are present in various habitats (e.g., forest and truffleground soils, etc.). ECM fungi, which are important both because of their economic value as edible fungi (i.e., truffles, boletes) and because of their application in reforestation projects, are the subject of this chapter, in which the recent advances in ECM fungal communities are reviewed, focusing mainly on the applicative aspects related to the use of these fungi.
\end{abstract}

A. Mello $\bullet$ R. Balestrini $(\bowtie)$

Istituto per la Protezione Sostenibile delle Piante del CNR, c/o Dipartimento di Scienze della Vita e

Biologia dei Sistemi, Università degli Studi di Torino, Viale Mattioli 25, 10125 Torino, Italy

e-mail: r.balestrini@ipp.cnr.it

\section{E. Zampieri}

Dipartimento di Scienze Agrarie, Forestali e Alimentari (DISAFA), Università degli Studi di Torino, Largo Paolo Braccini 2 (ex Via Leonardo da Vinci 44), 10095 Grugliasco (Torino), Italy

\section{Introduction}

Mycorrhizae are widespread symbiotic interactions between soil fungi and the roots of almost all land plants, including forest trees, grasses, and many crops (Smith and Read 2008). It has been estimated that about $90 \%$ of terrestrial plant species undergo an improvement in mineral nutrient uptake, thanks to root symbiosis with mycorrhizal fungi (Brundrett 2009), which, in turn, provide the fungus with carbon compounds (i.e., sugars). Several mycorrhizal associations exist, and these are identified primarily on the basis of the taxonomic 


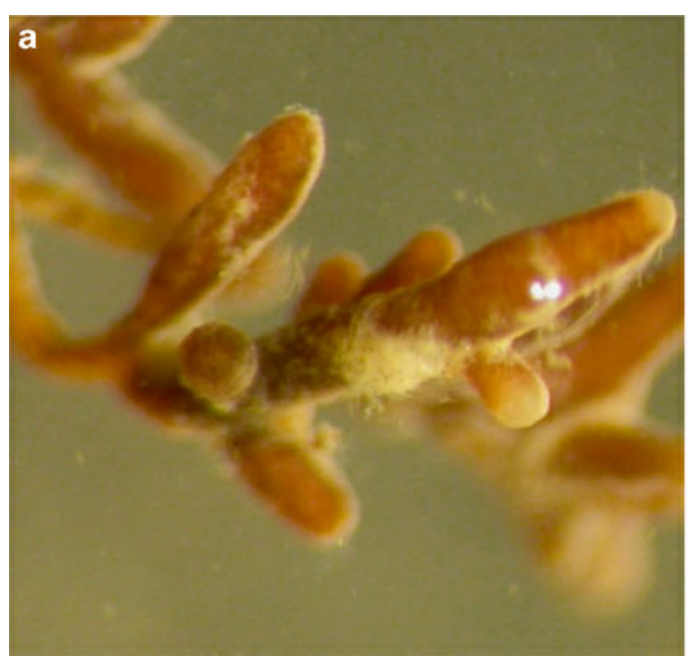

Fig. 16.1 (a) Corylus avellana/Tuber melanosporum ectomycorrhizae with the typical clavate aspect and the presence of external mycelium. (b) Paraffin oblique transverse section of a $C$. avellana/T. melanosporum ectomy-

identity of the hosts and the structural features of the symbiotic interfaces (Smith and Read 2008). According to the ability of the mycorrhizal fungus to penetrate the root cells, mycorrhizae can be divided into two main types: endomycorrhizae and ectomycorrhizae (Balestrini et al. 2012; Perotto et al. 2013).

In ECM symbiosis, which is the subject of this review, the fungus forms a hyphal sheath, called mantle, which is made of aggregated hyphae that surround the root surface, and the Hartig net, which is formed by the hyphae that penetrate between the root cells (Balestrini et al. 2012; Fig. 16.1). The mantle is thought to be responsible for the mineral nutrition and water uptake of the symbiotic tissues, while the Hartig net is considered the site in which metabolites are exchanged. A preliminary confirmation of the functional diversity of these two fungal compartments can be found in the study on Amanita muscaria ECMs by Nehls et al. (2001) in which the separation of the mantle from the ECM root, using only tweezers, underlined a differential expression for two hexose-regulated fungal genes. A specificity in the mantle and Hartig net transcriptomic profiles, which reflects a functional specificity, has recently been revealed by Hacquard et al. (2013) through a laser microdissection approach, in which the two fungal compartments

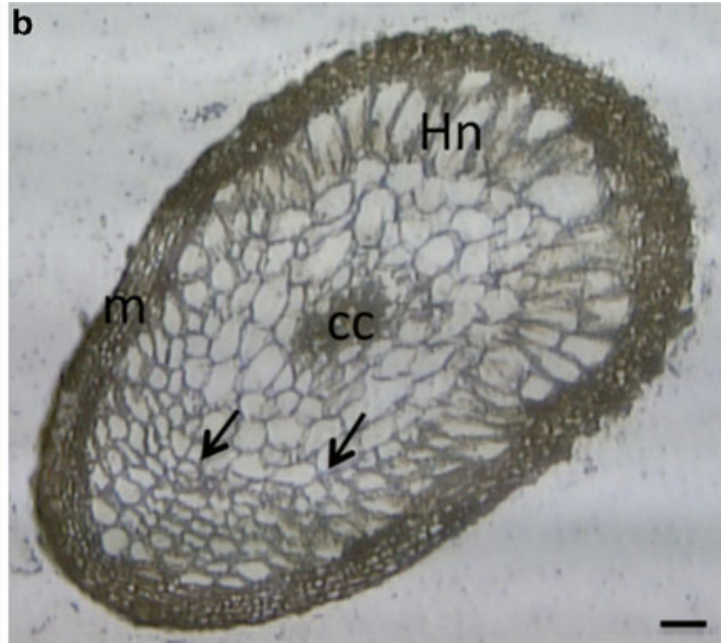

corrhiza showing the mantle $(\mathrm{m})$, which consists of several layers of hyphae, and the Hartig net proliferation (Hn and arrows). cc central cylinder. Bar corresponds to $25 \mu \mathrm{m}$

in truffle ECM were dissected, in combination with microarray gene expression analysis.

ECM fungi occur all over the world, and their host range includes most angiosperm and gymnosperm trees, as well as economically important timber-producing tree species. They play an important ecological role in woodland and forest communities in boreal, temperate, Mediterranean, and some subtropical forest ecosystems (Tedersoo et al. 2010a) that are dominated by hundreds of ECM fungal species (i.e., Basidio- and Ascomycetes), which form symbiotic associations with the lateral roots of trees and shrubs (Bonfante 2010). ECM symbiosis involves a relatively small number of plants, i.e., those belonging to Betulaceae, Dipterocarpaceae, Fagaceae, Nothofagaceae, Myrtaceae (e.g., Eucalyptus), Pinaceae, Salicaceae, and some genera of shrubs (e.g., Cistaceae), which are assisted by ECM fungi in the nutrition and protection against root diseases (Smith and Read 2008). As far as the fungal part is concerned, the majority of ECM fungi belong to Basidiomycetes, which can form macroscopic epigeous fruiting bodies that often grow next to tree trunks in woodlands, such as Boletus edulis and Cantharellus cibarius, while some others belong to Ascomycetes and form hypogeous fruiting bodies, such as truffles (Girlanda et al. 2007). 
ECM fungi in the soil are highly competitive for nutrient acquisition (Bücking et al. 2012 and reference therein), and their colonization allows plant access to $\mathrm{N}$ forms that are not so easily available to non-mycorrhizal plants (Hobbie and Hogberg 2012 and reference therein). In line with these observations, Averill et al. (2014) and the relative commentary by Bradford (2014) have suggested that the presence of greater stores of organic matter in forest soils dominated by ECM fungi, than in those dominated by arbuscular mycorrhizal (AM) fungi, could be due to a reduced nitrogen availability for the free-living microbes that use organic matter. Interestingly, when a tripartite interaction is present, as in the Alnus host system (N-fixing bacteria, ECM fungi, Alnus roots), the ECM fungal activity seems to be shifted toward a greater capacity for organic $\mathrm{P}$ acquisition (Walker et al. 2013). A study about the impact of an ECM fungus (Hebeloma cylindrosporum) on the potassium $\left(\mathrm{K}^{+}\right)$nutrition of its host plant (Pinus pinaster) has recently been performed, and the involvement of a fungal $\mathrm{K}^{+}$transporter has been investigated (Garcia et al. 2014). The results have shown that the $\mathrm{K}^{+}$nutrition of mycorrhizal pine plants was significantly improved under potassium-limiting conditions (Garcia et al. 2014).

A positive correlation between ECM symbiosis and plant performance in drought conditions has been reported (Morte et al. 2001; Dunabeitia et al. 2004; Alvarez et al. 2009), although plant response to drought can vary depending on the ECM fungal species (Dosskey et al. 1991; Kennedy and Peay 2007). More recently, a pot experiment, using Pinus sylvestris seedlings inoculated with several ECM fungi (Cenococcum geophilum, Paxillus involutus, Rhizopogon roseolus, and Suillus granulatus), has shown that only $S$. granulatus has a positive effect on shoot growth. Two different watering regimes (moist versus dry) were considered, and it was shown that $S$. granulatus effect on shoot growth was more pronounced under moist conditions (threefold increase) than under dry conditions (twofold increase), thus suggesting that the considered ECM fungus did not provide any additional support during drought stress (Kipfer et al. 2012). Danielsen and Polle (2014) have instead investigated the nutrient status and the physiological responses to drought of young poplar trees in the presence/ absence of the ECM fungus $P$. involutus, and they have been shown that root tips from ECM plants have a higher vitality than those from non-mycorrhizal plants. Since this effect is evident in both the colonized and non-colonized tips of ECM plants, the authors have suggested that it could be due to a general improved water supply to the roots of the host plants.

Numerous in situ ${ }^{13} \mathrm{CO}_{2}$ pulse-labeling experiments have been conducted on annual crops or grasslands to demonstrate a rapid carbon flux pathway from the host to the roots and from the roots to the rhizosphere (Robin et al. 1990; Nguyen et al. 1999; Johnson et al. 2002; Leake et al. 2006). The studies on carbon allocation in trees using pulse labeling have usually been performed in microcosms or mesocosms (Norton et al. 1990; Ek 1997; Simard et al. 1997), and only a few studies have been conducted in situ with adult trees but have never considered the fruiting bodies of the associated fungi (Högberg et al. 2008; Plain et al. 2009; Subke et al. 2009; Epron et al. 2011). Recently, Le Tacon et al. (2013) have elegantly assessed the allocation of carbon by the host to Tuber melanosporum mycorrhizae and ascocarps via an in situ ${ }^{13} \mathrm{CO}_{2}$ pulse-labeling experiment performed on a 20-year-old hazel tree in a truffle orchard established in the northeast of France. Almost all of the carbon allocated to the truffle ascocarps came from the host; thus, the hypothesis that it was mainly supplied via saprotrophic pathways was excluded. The development of truffles requires that carbon is stored in the trunk or roots of the host, and the process takes several weeks/months unlike what happens in an ectomycorrhizal member of Basidiomycotina producing fruiting bodies over a number of days (Teramoto et al. 2012). This result, as expected, demonstrates that the processes involved in carbon acquisition and ascocarp development are different from those of basidiocarps, since Tuber ascocarps take at least 6 months to grow between the production of the primordia and full ascocarp development, unlike Basidiomycota sporocarps, which develop over a number of days directly from diploid mycorrhizae. 
ECM symbiosis can therefore be considered a crucial component in nutrient cycling in sustainable forest ecosystem, and the current genome sequencing projects on ECM fungi are providing useful information to understand the functional and ecological roles for these fungi (Martin et al. 2008, 2010; Martin and Nehls 2009; Plett and Martin 2011; Martin and Bonito 2012; Balestrini et al. 2013; Marmeisse et al. 2013).

ECM fungi, which are therefore important for both their economic value (i.e., truffles, boletes) and their use in reforestation projects, are the subject of this chapter, in which the recent advances in ECM fungal communities are reviewed, focusing mainly on the applicative aspects related to the use of these fungi.

\section{Research on ECM Fungi: From the Past to the Present}

The study of ECM fungal diversity initially focused on the screening and molecular identification of fruiting bodies and, only later, on ECM tips, usually after sorting these in morphotypes (Horton and Bruns 2001; Mello et al. 2006a). As each ECM species is specialized in exploiting specific resources of the soil ecosystem, investigations have focused on the spatial distribution of the extraradical mycelium. Tracking the distribution of a given ECM fungus is considered difficult, since fruiting bodies do not reflect the distribution of ground networks (Dahlberg 2001). H. cylindrosporum was the first ECM fungus to be detected in soil (Guidot et al. 2002), and its presence was revealed within $50 \mathrm{~cm}$ from the fruiting bodies. Thanks to the use of the $\beta$-tubulin gene as a marker, Zampieri et al. (2010) were able to show that $T$. magnatum mycelium is more widespread than could be inferred from the distribution of its fruiting bodies and ECM and were able to identify a new haplotype that had never been described before from fruiting body material. The application of the denaturing gradient gel electrophoresis (DGGE) technique made it possible to discover that T. melanosporum is the dominant fungus in an area characterized by scanty vegetation, known as brûlé, which is associated to this fungus, and that Basidiomycota ECM fungi decrease within the brûlé, thus indicating a competitive effect of $T$. melanosporum on other ECM fungi (Napoli et al. 2010).

Since each individual within a species has its own functional traits, the next step toward a better understanding of the role of biodiversity in ecosystem functioning will need to consider the intraspecific diversity of mycorrhizal plants and fungi (Johnson et al. 2012).

The possibility of studying (micro)organisms directly in the field (metagenomics or environmental genomics, Chivian et al. 2008) thanks to the introduction of high-throughput sequencing techniques (i.e., 454 pyrosequencing) has given a strong impulse to the development of projects devoted to the study of fungal communities in different environments, including soils. The first studies on fungal diversity, which used a metagenomic approach in combination with highthroughput technology, appeared in 2009 (Buée et al. 2009; Jumpponen and Jones 2009). Buée and colleagues investigated fungal diversity in six different forest soils from a temperate French site using tag-encoded 454 pyrosequencing of the ITS-1 (nuclear ribosomal internal transcribed spacer-1), while Jumpponen and Jones (2009) studied the fungal communities in leaves of Quercus macrocarpa of trees located inside and outside a small urban center using the same molecular target. These authors have demonstrated that 454 pyrosequencing can be used successfully to study fungal communities in forest soil and phyllosphere. Starting from these first works, an approach based on 454 GS-FLX pyrosequencing has been widely used to investigate fungal communities in soils and has allowed new information to be provided on ECM fungal communities in several biomes/ecosystems, e.g., Swedish spruce plantations (Wallander et al. 2010); tropical African forests (Tedersoo et al. 2010b); truffle grounds (Mello et al. 2011); transgenic poplar plantations (soils and roots; Danielsen et al. 2012); ECM herb Bistorta vivipara roots on the Arctic archipelago of Svalbard (Blaalid et al. 2012, 2014); an urban landscape 
(Lothamer et al. 2013); a boreal forest (Clemmensen et al. 2013); boreal and tropical forests (McGuire et al. 2013); truffle grounds, a Mediterranean agro-silvo-pastoral system, serpentine substrates, and a contaminated industrial area (Orgiazzi et al. 2013); an oak-dominated forest in Japan (Toju et al. 2013); and three microsites (decayed wood, mineral soil adjacent to intact logs, control mineral soil) in mature spruce forests in British Columbia (Walker et al. 2014).

Global climate change is supposed to influence soil fungal communities, including ECM fungal communities. It has already been demonstrated that several ecological factors, disturbances (e.g., fire; Kipfer et al. 2011), and management practices (e.g., nitrogen deposition; Peter et al. 2001) affect the composition of ECM fungal communities and can lead to a reduction in the number of ECM fungal species (Koide et al. 2011). Changes in ECM fungal communities have recently been investigated using 454 pyrosequencing. Voř́šsková et al. (2014) have shown that seasonality and soil depth can influence ECM fungal communities in a temperate oak forest soil. A decrease in ECM fungi abundance has been verified in buried soils in the Siberian tundra (Gittel et al. 2013), where the abiotic conditions (low temperature and anoxia) seem to favor an abundance of bacteria, facultative anaerobic decomposers of soil organic matter (SOM) such as Actinobacteria, which increase compared to unburied soils. Hui et al. (2011) have observed, in a boreal coniferous forest site in Southern Finland, that a long-term exposition to $\mathrm{Pb}$ contamination can lead to a shift in the composition of the ECM community associated with the dominant pine ( $P$. sylvestris L.), as well as an increase in the abundance of the OTUs (operation taxonomic units) assigned to the Thelephora genus and a decrease in the frequency of OTUs corresponding to Pseudotomentella, Suillus, and Tylospora in the contaminated zone (Hui et al. 2011).

However, although several factors influence the composition of an ECM community and species richness of ECM fungi, the functional consequences of these shifts on the aboveground communities (e.g., for tree performance), as well as for the soil ecosystems, still require further investigation (Kipfer et al. 2012). An extensive metabolic reprogramming during the colonization between Laccaria bicolor and its compatible host Populus trichocarpa has recently been demonstrated. However, this extensive metabolic reprogramming is repressed in incompatible interactions where more defensive compounds are produced or retained (Tschaplinski et al. 2014). Moreover, Pena and Polle (2014) have demonstrated, using ${ }^{15} \mathrm{~N}$ isotope enrichment, that ECM assemblages provide advantages for inorganic $\mathrm{N}$ uptake mainly under environmental constraints with respect to unstressed plants, thus suggesting a stress activation of specific ECM taxa.

In addition to their ecological role, some ECM fungi such as Tricholoma matsutake, the socalled pine mushroom, have great value as commercial food. This mushroom is popular in Asia because of its aromatic odor and particular taste, as well as its high nutritional and medicinal value (Ohnuma et al. 2000; Kim et al. 2008; Ding et al. 2010). However, its annual production is limited, and several abiotic factors (e.g., rainfall and temperature) can affect it; moreover, attempts to cultivate it artificially have been unsuccessful. Kim and colleagues (2013) have investigated, through a 454 GS-FLX pyrosequencing platform, the fungal communities in soil where fruiting bodies develop. Several zones have been considered (inside, beneath, and outside the fairy ring zone of T. matsutake), with the aim of obtaining information on the fungal communities that could influence the development of the fruiting bodies. Mello et al. (2011) have used a similar approach to verify the fungal populations inside and outside the brûlé (burnt area), in which T. melanosporum fruiting bodies (the black truffles) are usually collected. The results show that Ascomycota, which was the most dominant phylum in the investigated French truffle ground, are more abundant inside than outside the brûle, while Basidiomycota increase outside the brûlé in agreement with previous results reported by Napoli et al. (2010) using the DDGE technique. 


\section{The Application of ECM Fungi to Field Projects}

ECM fungi provide trees with several benefits, such as the enhanced ability to absorb water, phosphorus, and nitrogen and protection from soilborne root pathogens such as Fusarium oxysporum. Evidence of the positive role of ECM Pisolithus albus in enhancing the growth of plants, such as Acacia spirorbis and Eucalyptus globulus, has been observed by significant increases in shoot and root biomass and mineral nutrition $(\mathrm{P}, \mathrm{K}$, and $\mathrm{Ca})$, as well as a limited metal uptake, acting as a protective barrier, in nickelrich ultramafic topsoils in New Caledonia (Jourand et al. 2014). In the restoration of ultramafic ecosystems degraded by mining activities, it could be convenient to isolate indigenous and stress-adapted beneficial ECM fungi in order to inoculate endemic plants (Jourand et al. 2014). ECM fungi have already been proposed for the ecological restoration of mine sites (in particular chromium and nickel mines) in Australia by Reddell et al. (1999) and in New Caledonia by Perrier et al. (2006) as well as in the post-mining of bauxite in Brazil by Khosla and Reddy (2008). ECM fungi are also expected to play a key role in forest regeneration after major disturbance events such as stand-replacing forest fires. Kipfer et al. (2010) investigated the heat tolerance of ECM fungi of Scots pine. They verified that 60 and $70{ }^{\circ} \mathrm{C}$ reduced the mean of the species, but not $45^{\circ} \mathrm{C}$. The composition changed because of heat, but most of the ECM fungi, such as $R$. roseolus, $C$. geophilum, and several unidentified species, survived.

Sustainable soil ecosystem services require the management of the beneficial soil organisms that are considered of economic value and which are available in the market for their application. Reforestation using container-grown seedlings of $P$. pinaster produced in nurseries is a common practice in many countries. Fertilizers are often used in nurseries. However, the use of chemical fertilizers can constitute a threat to the environment, in addition to modifying nutrient availability of the fertilized seedlings, which may not be able to adapt to forest soil conditions when transplanted.
Sousa et al. (2012) showed that selected ECM fungi could be used as a beneficial biotechnological tool in the nursery production of $P$. pinaster, without the need of fertilizers. Oliveira et al. (2012) found that inoculation with selected ECM fungi can be an advantageous ecotechnological approach that can be used to improve the nursery production of $P$. pinaster. The inoculation of Chinese pine (Pinus tabulaeformis Carr.) seedlings with Boletus luridus, under field experimental conditions, has shown to significantly influence bacterial functional diversity in the rhizosphere of $P$. tabulaeformis seedlings, thus highlighting the importance of the application of ECM fungal inoculum in order to promote microbial community diversity of soil in forest restoration projects (Zhang et al. 2010).

The fast growth rate of American chestnut, coupled with its quality timber, makes it a desired species for use in reforestation projects. Bauman et al. (2013) have evaluated various soil preparation methods that promote ECM colonization and American chestnut Castanea dentata establishment in coal mine restoration projects. Quercus ilex forests play ecological and socioeconomic roles by protecting the environment and providing wood, forage resources, and tourism. Oliveira et al. (2010) considered the management of nursery practices for efficient ECM fungi application in order to establish $Q$. ilex plantations. The ECM inoculants could be rhizosphere soil from forests, spores, or vegetative mycelia, although the soil from forests has the disadvantage of perhaps containing both beneficial (e.g., mycorrhizal fungi) and harmful (pathogenic fungi) microorganisms. The use of spores or vegetative mycelia of ECM fungi seems to be the most convenient and practical technique although the supply of spores is limited by the onset of the rainy season and the maturing of the fruiting bodies. Aggangan et al. (2012) have developed a protocol for the production of quality rooted cuttings for plantation establishment or enrichment planting in the red soil of Caliraya, Philippines, of Anisoptera thurifera (Blanco) Blume and Shorea guiso (Blanco) Blume, which belong to the Dipterocarpaceae, the most important tree family in the tropical forests of southeast Asia, and are considered as endangered species. These authors have shown 
that ECM mycelia entrapped in alginate beads are effective in promoting the growth and $\mathrm{P}$ uptake of $A$. thurifera and $S$. guiso. Immobilized mycelium offers more advantages than nonimmobilized inoculum such as longer survival in the soil, easy storage, and greater viability. However, the cultivation in fermenters or in bioreactors for the large-scale production of mycelial inoculum may compromise the quality of the inoculum and thus limit the application of this technique. Forecasting the response of ECM fungi to environmental changes represents an important step in maintaining forest productivity for the future. Jarvis et al. (2013) have analyzed and identified fungal communities from 15 seminatural Scots pine $(P$. sylvestris L.) forests through ITS sequencing. Their data have demonstrated an important effect of rainfall and soil moisture on community composition at the species level and less influence of temperature on the abundance of ECM exploration types. Valdés et al. (2006) observed that a severe drought had an important effect on both total fine-root biomass and the ECM-root biomass in a tropical pine forest and suggested that forest management practices should consider the effects of drought in reducing the capacity of Pinus oaxacana to form ECM.

\section{Food Applications and Toxicity of ECM Fungi}

Fungi are the most productive biological sources of primary and secondary metabolites that have long been exploited by the pharmaceutical and food industries. Some of them, such as Boletus species, are also an important source of proteins, carbohydrates, fatty acids (mainly linoleic acid), sugars (mainly mannitol and trehalose), and vitamins (tocopherols and ascorbic acid), as well as phenolic acids (Heleno et al. 2011). Since phenolic acids have antioxidative properties, they are currently being exploited by food and pharmaceutical industries. Important antioxidative properties have been found for polysaccharides extracted from $B$. edulis, and these could be employed as ingredients in healthy food to alleviate oxidative stress (Zhang et al. 2011). A lectin with antitumoral properties has also been found, thus opening new perspectives in research, with the aim of developing new drugs for cancer therapies (Bovi et al. 2011). A homologous of the sugar-binding antiviral protein cyanovirin- $\mathrm{N}$ $(\mathrm{CVN})$, previously identified in the cyanobacterium Nostoc ellipsosporum, has been found by analysis of transcript sequences deriving from a gene expression profiling study conducted in the truffle Tuber borchii, and a novel protein family has been described in filamentous fungi and in the fern Ceratopteris richardii (Percudani et al. 2005). It has been proposed that these findings provide candidate polypeptides to be tested as antiviral agents (Percudani et al. 2005). Two genes coding for putative lectins belonging to the CVNH (CyanoVirin-N Homolog) family have also been found in T. melanosporum genome (http://mycor.nancy.inra.fr/IMGC/Tuber Genome/index.html). However, preliminary results have shown that TbCVNH (the CVNH discovered in $T$. borchii) seems to be completely inactive in the antiviral activity test (Koharudin et al. 2008). Mushrooms produce particular aroma compounds that are of interest for industrial applications, such as 1-octen-3-ol, which is often added as flavoring to processed products in order to reintegrate its loss which occurs during the preparation of these food products (ZawirskaWojtasiak 2004). Long-chain unsaturated fatty acids, such as palmitoleic acid and linoleic acid, show antibacterial activity and are used as antimicrobial food additives (Zheng et al. 2005). To date, more than 200 volatile organic compounds have been described from various truffle species, and the biosynthetic pathways involved in volatile biosynthesis have been traced in the genome of a mushroom that is highly appreciated for its special taste and aroma, the black truffle T. melanosporum (Martin et al. 2010). From the ecological point of view, truffle volatiles are used to attract mammals and insects, which are thus able to locate the precious hypogeous fungi, feed on them, and spread their spores. In addition, truffle volatiles diffuse in the soil and mediate complex interactions with microorganisms and plant roots (Splivallo et al.2011; Mello et al.2013). Truffles and porcini are greatly appreciated throughout the world, both as fresh fruiting bodies and as ingredients in processed products (Mello 2012). 
A qPCR assay has been developed to authenticate and quantify T. magnatum and T. melanosporum in food matrices that have undergone intensive transformation processes, such as cream and butter (Rizzello et al. 2012). This method is promising in detecting the incorrect labeling of processed products and can therefore be used to protect the consumer and to assess food quality. The rapid identification of mushroom poisoning, which continues to be a public health concern in Europe, the USA, and several other parts of the world, is particularly important. The majority of reported fatal intoxications have been attributed to a few species of the Amanita genus and in particular to the death cap Amanita phalloides, which can cause a high mortality rate (10-30 \% in adults). A. phalloides are often mistaken in appearance for nonpoisonous species, and the ingestion of one single mushroom cap may be sufficient to cause death within 2-8 days (Gausterer et al. 2014). Besides the previous publications that have reported the use of conventional and real-time PCR in the cases of suspected mushroom poisoning as an alternative to morphological investigations and as a complementary approach to toxicological analyses, an article on a rapid and sensitive detection of genetic traces from poisonous mushrooms in a variety of matrices, including raw, fried, and digested mushroom homogenates, spiked feces, and clinical samples (vomit, stool), has just been published by Gausterer et al. (2014). Mushrooms belonging to the Boletus edulis sensu lato group, a complex of at least four species of ECM fungi in the genus Boletus section Boletus (Singer 1986), constitute an interesting example of contrasting fungal features. These fruiting bodies are in fact in high demand as mushrooms because of their pleasant flavor and texture, but at the same time, they have been shown to induce allergic symptoms either through inhalation, ingestion, or contact (Helbling et al. 2002). In order to guarantee safe naturally derived food, Mello et al. (2006b) developed specific primers for the unambiguous detection of $B$. edulis sensu stricto, $B$. aereus, $B$. pinophilus, and $B$. aestivalis. In addition, the relationships of $B$. violaceofuscus with the members of $B$. edulis s.l. have been examined.
The data that will be obtained from the B. edulis genome sequencing project, which is currently in progress, will surely allow our knowledge on its allergenic potential and the presence of allergen orthologues to be improved. Thanks to the availability of the genome sequence, an extremely low allergenic potential and the lack of key mycotoxin biosynthetic enzymes have been found in the black truffle T. melanosporum (Martin et al. 2010).

Acknowledgments EZ's fellowship was funded by a grant from the Italian Ministry of Education, University and Research, as part of the FIRB program (Project DEFINE; grant number RBFR128ONN).

\section{References}

Aggangan NS, Aggangan JS, Charisse J, Bulan O, Limos CAS (2012) Inoculation of Dipterocarps Anisoptera thurifera and Shorea guiso with ectomycorrhizal fungi in Philippine red soil. Philipp J Sci 141:229-241

Alvarez M, Huygens D, Olivares E, Saavedra I, Alberdi M, Valenzuela E (2009) Ectomycorrhizal fungi enhance nitrogen and phosphorus nutrition of Nothofagus dombeyi under drought conditions by regulating assimilative enzyme activities. Physiol Plant 136:426-436

Averill C, Turner BL, Finzi AC (2014) Mycorrhizamediated competition between plants and decomposers drives soil carbon storage. Nature 505:543-545

Balestrini R, Bianciotto V, Bonfante P (2012) Mycorrhizae. In: Huang PM, Li Y, Sumner ME (eds) Handbook of soil sciences: properties and processes, vol 24, 2nd edn. CRC Press, Boca Raton, pp 29-39

Balestrini R, Ghignone S, Sillo F (2013) The contribution of new technologies toward understanding plant-fungus symbioses. In: Arora NK (ed) Plant microbe symbiosis: fundamentals and advances. Springer, New Delhi, pp 201-214

Bauman JM, Keiffer CH, Hiremath S, McCarthy BC (2013) Soil preparation methods promoting ectomycorrhizal colonization and American chestnut Castanea dentate establishment in coal mine restoration. J Appl Ecol 50:721-729

Blaalid R, Carlsen T, Kumar S, Halvorsen R, Ugland KI, Fontana G, Kauserud H (2012) Changes in the root-associated fungal communities along a primary succession gradient analysed by 454 pyrosequencing. Mol Ecol 21:1897-1908

Blaalid R, Davey ML, Kauserud H, Carlsen T, Halvorsen R, Høiland K, Eidesen PB (2014) Arctic rootassociated fungal community composition reflects environmental filtering. Mol Ecol 23:649-659 
Bonfante P (2010) Plant-fungal interactions in mycorrhizas. In: Encyclopedia of Life Sciences (ELS). John Wiley \& Sons Ltd, Chichester

Bovi M, Carrizo ME, Capaldi S, Perduca M, Chiarelli LR, Galliano M, Monaco HL (2011) Structure of a lectin with antitumoral properties in king bolete (Boletus edulis) mushrooms. Glycobiology 21:1000-1009

Bradford MA (2014) Ecology: good dirt with good friends. Nature 505:486-487

Brundrett MC (2009) Mycorrhizal associations and other means of nutrition of vascular plants: understanding the global diversity of host plants by resolving conflicting information and developing reliable means of diagnosis. Plant Soil 320:37-77

Bücking H, Liepold E, Ambilwade P (2012) The role of the mycorrhizal symbiosis in nutrient uptake of plants and the regulatory mechanisms underlying these transport processes. In: Dhal NK, Sahu SC (eds) Plant science. Intech, Janeza Trdine, p 107

Buée M, Reich M, Murat C, Morin E, Nilsson RH, Uroz S, Martin F (2009) 454 pyrosequencing analyses of forest soil reveal an unexpected high fungal. New Phytol 184:449-456

Chivian D, Brodie EL, Alm EJ, Culley DE, Dehal PS, DeSantis TZ, Gihring TM, Lapidus A, Lin LH, Lowry SR, Moser DP, Richardson PM, Southam G, Wanger G, Pratt LM, Andersen GL, Hazen TC, Brockman FJ, Arkin AP, Onstott TC (2008) Environmental genomics reveals a single-species ecosystem deep within earth. Science 322:275-278

Clemmensen KE, Bahr A, Ovaskainen O, Dahlberg A, Ekblad A, Wallander H, Stenlid J, Finlay RD, Wardle DA, Lindahl BD (2013) Roots and associated fungi drive long-term carbon sequestration in boreal forest. Science 339:1615-1618

Dahlberg A (2001) Community ecology of ectomycorrhizal fungi: an advancing interdisciplinary field. New Phytol 150:555-562

Danielsen L, Polle A (2014) Poplar nutrition under drought as affected by ectomycorrhizal colonization. Environ Exp Bot 108:89-98

Danielsen L, Thürmer A, Meinicke P, Buée M, Morin E, Martin F, Pilate G, Daniel R, Polle A, Reich M (2012) Fungal soil communities in a young transgenic poplar plantation form a rich reservoir for fungal root communities. Ecol Evol 2:1935-1948

Ding X, Tang J, Cao M, Guo CX, Zhang X, Zhong J, Zhang J, Sun Q, Feng S, Yang ZR, Zhao J (2010) Structure elucidation and antioxidant activity of a novel polysaccharide isolated from Tricholoma matsutake. Int J Biol Macromol 47:271-275

Dosskey MG, Boersma L, Linderman RG (1991) Role of photosynthate demand of ectomycorrhizas in the response of Douglas fir seedlings to drying soil. New Phytol 117:327-334

Duñabeitia MK, Hormilla S, Garcia-Plazaola JI, Txarterina K, Arteche U, Becerril JM (2004) Differential responses of three fungal species to environmental factors and their role in the mycorrhization of Pinus radiata D. Don. Mycorrhiza 14:11-18
Ek H (1997) The influence of nitrogen fertilization on the carbon economy of Paxillus involutus in ectomycorrhizal association with Betula pendula. New Phytol 135:133-142

Epron D, Ngao J, Dannoura M, Bakker MR, Zeller B, Bazot S, Bosc A, Plain C, Lata JC, Priault P, Barthes L, Loustau D (2011) Seasonal variations of belowground carbon transfer assessed by in situ ${ }^{13} \mathrm{CO}_{2}$ pulse labelling of trees. Biogeosciences 8:1153-1168

Garcia K, Delteil A, Conéjéro G, Becquer A, Plassard C, Sentenac H, Zimmermann S (2014) Potassium nutrition of ectomycorrhizal Pinus pinaster: overexpression of the Hebeloma cylindrosporum HcTrk1 transporter affects the translocation of both $\mathrm{K}(+)$ and phosphorus in the host plant. New Phytol 201:951-960

Gausterer C, Penker M, Krisai-Greilhuber I, Stein C, Stimpfl T (2014) Rapid genetic detection of ingested Amanita phalloides. Forensic Sci Int Genet 9:66-71

Girlanda M, Perotto S, Bonfante P (2007) Mycorrhizal fungi: their habitats and nutritional strategies biology of the fungal cell. In: Howard RJ, Gow NAR (eds) The Mycota IV, 2nd edn. Springer, Berlin

Gittel A, Bárta J, Kohoutová I, Mikutta R, Owens S, Gilbert J, Schnecker J, Wild B, Hannisdal B, Maerz J, Lashchinskiy N, Capek P, Santruková H, Gentsch N, Shibistova O, Guggenberger G, Richter A, Torsvik VL, Schleper C, Urich T (2013) Distinct microbial communities associated with buried soils in the Siberian tundra. ISME J 8:841-853

Guidot A, Debaud JC, Marmeisse R (2002) Spatial distribution of the below-ground mycelia of an ectomycorrhizal fungus inferred from specific quantification of its DNA in soil samples. FEMS Microbiol Ecol 42:477-486

Hacquard S, Tisserant E, Brun A, Legué V, Martin F, Kohler A (2013) Laser microdissection and microarray analysis of Tuber melanosporum ectomycorrhizas reveal functional heterogeneity between mantle and Hartig net compartments. Environ Microbiol 15:1853-1869

Helbling A, Bonadies N, Brander KA, Pichler WJ (2002) Boletus edulis: a digestion-resistant allergen may be relevant for food allergy. Clin Exp Allergy 32:771-775

Heleno SA, Barros L, Sousa MJ, Martins A, SantosBuelga C, Ferreira ICFR (2011) Targeted metabolites analysis in wild Boletus species. LWT Food Sci Technol 44:1343-1348

Hobbie EA, Högberg P (2012) Nitrogen isotopes link mycorrhizal fungi and plants to nitrogen dynamics. New Phytol 196:367-382

Högberg P, Högberg MN, Gottlicher SG, Betson NR, Keel SG, Metcalfe DB, Campbell C, Schindlbacher A, Hurry V, Lundmark T, Linder S, Nasholm T (2008) High temporal resolution tracing of photosynthate carbon from the tree canopy to forest soil microorganisms. New Phytol 177:220-228

Horton TR, Bruns TD (2001) The molecular revolution in ectomycorrhizal ecology: peeking into the black-box. Mol Ecol 10:1855-1871 
Hui N, Jumpponen A, Niskanen T, Liimatainen K, Jones KL, Koivula T, Romantschuk M, Strömmer R (2011) ECM fungal community structure, but not diversity, altered in a $\mathrm{Pb}$-contaminated shooting range in a boreal coniferous forest site in Southern Finland. FEMS Microbiol Ecol 76:121-132

Jarvis S, Woodward S, Alexander IJ, Taylor AF (2013) Regional scale gradients of climate and nitrogen deposition drive variation in ectomycorrhizal fungal communities associated with native Scots pine. Glob Chang Biol 19:1688-1696

Johnson D, Leake JR, Ostle N, Ineson P, Read DJ (2002) In situ ${ }^{13} \mathrm{CO}_{2}$ pulse-labelling of upland grassland demonstrates a rapid pathway of carbon flux from arbuscular mycorrhizal mycelia to the soil. New Phytol 153:327-334

Johnson D, Martin F, Cairney JW, Anderson IC (2012) The importance of individuals: intraspecific diversity of mycorrhizal plants and fungi in ecosystems. New Phytol 19:614-628

Jourand P, Hannibal L, Majorel C, Mengant S, Ducousso M, Lebrun M (2014) Ectomycorrhizal Pisolithus albus inoculation of Acacia spirorbis and Eucalyptus globulus grown in ultramafic topsoil enhances plant growth and mineral nutrition while limits metal uptake. J Plant Physiol 171:164-172

Jumpponen A, Jones KL (2009) Massively parallel 454 sequencing indicates hyperdiverse fungal communities in temperate Quercus macrocarpa phyllosphere. New Phytol 184:438-448

Kennedy PG, Peay KG (2007) Different soil moisture conditions change the outcome of the ectomycorrhizal symbiosis between Rhizopogon species and Pinus muricata. Plant Soil 291:155-165

Khosla B, Reddy MS (2008) Response of ectomycorrhizal fungi on the growth and mineral nutrition of Eucalyptus seedlings in bauxite mined soil. Am-Eurasian J Agric Environ Sci 3:123-126

Kim JY, Byeon SE, Lee YG, Lee JY, Park J, Hong EK, Cho JY (2008) Immunostimulatory activities of polysaccharides from liquid culture of pine-mushroom Tricholoma matsutake. J Microbiol Biotechnol 18:95-103

Kim M, Yoon H, You YH, Kim YE, Woo JR, Seo Y, Lee GM, Kim YJ, Kong WS, Kim JG (2013) Metagenomic analysis of fungal communities inhabiting the fairy ring zone of Tricholoma matsutake. J Microbiol Biotechnol 23:1347-1356

Kipfer T, Egli S, Ghazoul J, Moser B, Wohlgemuth T (2010) Susceptibility of ectomycorrhizal fungi to soil heating. Fungal Biol 114:467-472

Kipfer T, Moser B, Egli S, Wohlgemuth T, Ghazoul J (2011) Ectomycorrhiza succession patterns in Pinus sylvestris forests after stand-replacing fire in the Central Alps. Oecologia 167:219-228

Kipfer T, Wohlgemuth T, van der Heijden MG, Ghazoul J, Egli S (2012) Growth response of drought-stressed Pinus sylvestris seedlings to single- and multi-species inoculation with ectomycorrhizal fungi. PLoS ONE 7:e35275
Koharudin LMI, Viscomi AR, Jee J-G, Ottonello S, Gronenborn AM (2008) The evolutionarily conserved family of Cyanovirin-N homologs: structures and carbohydrate specificity. Structure 16:570-584

Koide RT, Fernandez C, Petprakob K (2011) General principles in the community ecology of ectomycorrhizal fungi. Ann For Sci 68:45-55

Le Tacon F, Zeller B, Plain C, Hossann C, Bréchet C, Robin C (2013) Carbon transfer from the host to Tuber melanosporum mycorrhizas and ascocarps followed using a ${ }^{13} \mathrm{C}$ pulse-labeling technique. PLoS ONE 8:e64626

Leake JR, Ostle NJ, Rangel-Castro JI, Johnson D (2006) Carbon fluxes from plants through soil organisms determined by field ${ }^{13} \mathrm{CO}_{2}$ pulse-labelling in an upland grassland. Appl Soil Ecol 33:152-175

Lothamer K, Brown SP, Mattox JD, Jumpponen A (2013) Comparison of root-associated communities of native and non-native ectomycorrhizal hosts in an urban landscape. Mycorrhiza 24:267-280

Marmeisse R, Nehls U, Opik M, Selosse MA, Pringle A (2013) Bridging mycorrhizal genomics, metagenomics and forest ecology. New Phytol 198:343-346

Martin F, Bonito G (2012) Ten years of genomics for ectomycorrhizal fungi: what have we achieved and where are we heading? In: Zambonelli A, Bonito GM (eds) Edible ectomycorrhizal mushrooms, vol 34, Soil biology. Springer, Berlin/Heidelberg, pp 383-401

Martin F, Nehls U (2009) Harnessing ectomycorrhizal genomics for ecological insights. Curr Opin Plant Biol 12:508-515

Martin F, Aerts A, Ahrén D, Brun A, Danchin EG, Duchaussoy F, Gibon J, Kohler A, Lindquist E, Pereda V, Salamov A, Shapiro HJ, Wuyts J, Blaudez D, Buée M, Brokstein P, Canbäck B, Cohen D, Courty PE, Coutinho PM, Delaruelle C, Detter JC, Deveau A, DiFazio S, Duplessis S, Fraissinet-Tachet L, Lucic E, Frey-Klett P, Fourrey C, Feussner I, Gay G, Grimwood J, Hoegger PJ, Jain P, Kilaru S, Labbé J, Lin YC, Legué V, Le Tacon F, Marmeisse R, Melayah D, Montanini B, Muratet M, Nehls U, Niculita-Hirzel H, Oudot-Le Secq MP, Peter M, Quesneville H, Rajashekar B, Reich M, Rouhier N, Schmutz J, Yin T, Chalot M, Henrissat B, Kües U, Lucas S, Van de Peer Y, Podila GK, Polle A, Pukkila PJ, Richardson PM, Rouzé P, Sanders IR, Stajich JE, Tunlid A, Tuskan G, Grigoriev IV (2008) The genome of Laccaria bicolor provides insights into mycorrhizal symbiosis. Nature 452:88-92

Martin F, Kohler A, Murat C, Balestrini R, Coutinho PM, Jaillon O, Montanini B, Morin E, Noel B, Percudani R, Porcel B, Rubini A, Amicucci A, Amselem J, Anthouard V, Arcioni S, Artiguenave F, Aury JM, Ballario P, Bolchi A, Brenna A, Brun A, Buée M, Cantarel B, Chevalier G, Couloux A, Da Silva C, Denoeud F, Duplessis S, Ghignone S, Hilselberger B, Iotti M, Marçais B, Mello A, Miranda M, Pacioni G, Quesneville H, Riccioni C, Ruotolo R, Splivallo R, Stocchi V, Tisserant E, Viscomi AR, Zambonelli A, Zampieri E, Henrissat B, Lebrun MH, Paolocci F, 
Bonfante P, Ottonello S, Wincker P (2010) Périgord black truffle genome uncovers evolutionary origins and mechanisms of symbiosis. Nature 464:1033-1038

McGuire KL, Allison SD, Fierer N, Treseder KK (2013) Ectomycorrhizal-dominated boreal and tropical forests have distinct fungal communities, but analogous spatial patterns across soil horizons. PLoS ONE 8:e68278

Mello A (2012) State of the art of the research on Boletus edulis. In: Zambonelli A, Bonito GM (eds) Edible ectomycorrhizal mushrooms: current knowledge and future prospects, vol 34, Soil biology. Springer, Berlin, p 73

Mello A, Ghignone S, Vizzini A, Sechi C, Ruiu P, Bonfante $P$ (2006a) ITS primers for the identification of marketable Boletes. J Biotechnol 121:318-329

Mello A, Murat C, Bonfante P (2006b) Truffles: much more than a prized and local fungal delicacy. FEMS Microbiol Lett 260:1-8

Mello A, Napoli C, Murat C, Morin E, Marceddu G, Bonfante P (2011) ITS-1 versus ITS-2 pyrosequencing: a comparison of fungal populations in truffle grounds. Mycologia 103:1184-1193

Mello A, Ding GC, Piceno YM, Napoli C, Tom LM, DeSantis TZ, Andersen GL, Smalla K, Bonfante P (2013) Truffle brûlés have an impact on the diversity of soil bacterial communities. PLoS ONE 8:e61945

Morte A, Díaz G, Rodríguez P, Alarcón JJ, SánchezBlanco MJ (2001) Growth and water relations in mycorrhizal and nonmycorrhizal Pinus halepensis plants in response to drought. Biol Plant 44:263-267

Napoli C, Mello A, Borra A, Vizzini A, Sourzat P, Bonfante P (2010) Tuber melanosporum, when dominant, affects fungal dynamics in truffle-grounds. New Phytol 185:237-247

Nehls U, Mikolajewski S, Magel E, Hampp R (2001) Carbohydrate metabolism in ectomycorrhizas: gene expression, monosaccharide transport and metabolic control. New Phytol 150:533-541

Nguyen C, Todorovic C, Robin C, Christophe A, Guckert A (1999) Continuous monitoring of rhizosphere respiration after labelling of plant shoots with ${ }^{14} \mathrm{CO}_{2}$. Plant Soil 212:189-199

Norton JM, Smith JL, Firestone MK (1990) Carbon flow in the rhizosphere of Ponderosa pine seedlings. Soil Biol Biochem 22:449-455

Ohnuma N, Amemiya K, Kakuda R, Yaoita Y, Machida K, Kikuchi M (2000) Sterol constituents from two edible mushrooms, Lentinula edodes and Tricholoma matsutake. Chem Pharm Bull (Tokyo) 48:749-751

Oliveira RS, Franco AR, Vosátka M, Castro PML (2010) Management of nursery practices for efficient ectomycorrhizal fungi application in the production of Quercus ilex. Symbiosis 52:125-131

Oliveira RS, Franco AR, Castro PML (2012) Combined use of Pinus pinaster plus and inoculation with selected ectomycorrhizal fungi as an ecotechnology to improve plant performance. Ecol Eng 43:95-103

Orgiazzi A, Bianciotto V, Bonfante P, Daghino S, Ghignone S, Lazzari A, Lumini E, Mello A, Napoli C, Perotto S, Vizzini A, Bagella S, Murat C, Girlanda M
(2013) 454 pyrosequencing analysis of fungal assemblages from geographically distant, disparate soils reveals spatial patterning and a core mycobiome. Diversity 5:73-98

Pena R, Polle A (2014) Attributing functions to ectomycorrhizal fungal identities in assemblages for nitrogen acquisition under stress. ISME J 8:321-330

Percudani R, Montanini B, Ottonello S (2005) The antiHIV cyanovirin-N domain is evolutionarily conserved and occurs as a protein module in eukaryotes. Proteins 60:670-678

Perotto S, Angelini P, Bianciotto V, Bonfante P, Girlanda M, Kull T, Mello A, Pecoraro L, Perini C, Persiani AM, Saitta A, Sarrocco S, Vannacci G, Venanzoni R, Venturella G, Selosse MA (2013) Interactions of fungi with other organisms. Plant Biosyst 147:208-218

Perrier N, Amir H, Colin F (2006) Occurrence of mycorrhizal symbioses in the metal-rich lateritic soils of the Koniambo Massif, New Caledonia. Mycorrhiza 16:449-458

Peter M, Ayer F, Egli S (2001) Nitrogen addition in a Norway spruce stand altered macromycete sporocarp production and belowground ectomycorrhizal species composition. New Phytol 149:311-325

Plain C, Gerant D, Maillard P, Dannoura M, Dong Y, Zeller B, Priault P, Parent F, Epron D (2009) Tracing of recently assimilated carbon in respiration at high temporal resolution in the field with a tuneable diode laser absorption spectrometer after in situ ${ }^{13} \mathrm{CO}_{2}$ pulse labelling of 20-year-old beech trees. Tree Physiol 29:1433-1445

Plett JM, Martin F (2011) Blurred boundaries: lifestyle lessons from ectomycorrhizal fungal genomes. Trends Genet 27:14-22

Reddell P, Gordon V, Hopkins MS (1999) Ectomycorrhizas in Eucalyptus tetrodonta and E. miniata forest communities in tropical Northern Australia and their role in the rehabilitation of these forests following mining. Aust J Bot 47:881-907

Rizzello R, Zampieri E, Vizzini A, Autino A, Cresti M, Bonfante P, Mello A (2012) Authentication of prized white and black truffles in processed products using quantitative real-time PCR. Food Res Int 48:792-797

Robin C, Vaillant V, Vansuyt G, Zinsou C (1990) Assimilate partitioning in Pachyrhizus erosus L. during long-day vegetative development. Plant Physiol Biochem 28:343-349

Simard SW, Durall DM, Jones MD (1997) Carbon allocation and carbon transfer between Betula papyrifera and Pseudotsuga menziesii seedlings using a ${ }^{13} \mathrm{C}$ pulse-labeling method. Plant Soil 191:41-55

Singer R (1986) The agaricales in modern taxonomy, 4th edn. Koeltz Scientific Books, Koenigstein, p 981

Smith SE, Read DJ (2008) Mycorrhizal symbiosis, 3rd edn. Academic, London

Sousa NR, Franco AR, Oliveira RS, Castro PML (2012) Ectomycorrhizal fungi as an alternative to the use of chemical fertilisers in nursery production of Pinus pinaster. J Environ Manag 95:S269-S274 
Splivallo R, Ottonello S, Mello A, Karlovsky P (2011) Truffle volatiles: from chemical ecology to aroma biosynthesis. New Phytol 189:688-699

Subke JA, Vallack HW, Magnusson T, Keel SG, Metcalfe DB, Högberg P, Ineson P (2009) Short-term dynamics of abiotic and biotic soil ${ }^{13} \mathrm{CO}_{2}$ effluxes after in situ ${ }^{13} \mathrm{CO}_{2}$ pulse labelling of a boreal pine forest. New Phytol 183:349-357

Tedersoo L, May TW, Smith ME (2010a) Ectomycorrhizal lifestyle in fungi: global diversity, distribution, and evolution of phylogenetic lineages. Mycorrhiza 20:217-263

Tedersoo L, Nilsson RH, Abarenkov K, Jairus T, Sadam A, Saar I, Bahram M, Bechem E, Chuyong G, Kõljalg U (2010b) 454 Pyrosequencing and Sanger sequencing of tropical mycorrhizal fungi provide similar results but reveal substantial methodological biases. New Phytol 188:291-301

Teramoto M, Wu B, Hogetsu T (2012) Transfer of ${ }^{14} \mathrm{C}$-photosynthate to the sporocarp of an ectomycorrhizal fungus Laccaria amethystina. Mycorrhiza 22:219-225

Toju H, Yamamoto S, Sato H, Tanabe AS, Gilbert GS, Kadowaki K (2013) Community composition of rootassociated fungi in a Quercus-dominated temperate forest: "codominance" of mycorrhizal and rootendophytic fungi. Ecol Evol 3:1281-1293

Tschaplinski TJ, Plett JM, Engle N, Deveau A, Cushman K, Martin MZ, Doktycz MJ, Tuskan G, Brun A, Kohler A, Martin FM (2014) Populus trichocarpa and Populus deltoides exhibit different metabolomic responses to colonization by the symbiotic fungus Laccaria bicolor. Mol Plant Microbe Interact 6:546-556

Valdés M, Asbjornsen H, Gómez-Cárdenas M, Juárez M, Vogt KA (2006) Drought effects on fine-root and ectomycorrhizal-root biomass in managed Pinus oaxacana Mirov stands in Oaxaca, Mexico. Mycorrhiza 16:117-124
Voříšková J, Brabcová V, Cajthaml T, Baldrian P (2014) Seasonal dynamics of fungal communities in a temperate oak forest soil. New Phytol 201:269-278

Walker JK, Cohen H, Higgins LM, Kennedy PG (2013) Testing the link between community structure and function for ectomycorrhizal fungi involved in a global tripartite symbiosis. New Phytol 202:287-296

Walker JKM, Phillips LA, Jones MD (2014) Ectomycorrhizal fungal hyphae communities vary more along a $\mathrm{pH}$ and nitrogen gradient than between decayed wood and mineral soil microsites. Botany 92:453-463

Wallander H, Johansson U, Sterkenburg E, Brandström Durling M, Lindahl BD (2010) Production of ectomycorrhizal mycelium peaks during canopy closure in Norway spruce forests. New Phytol 187:1124-1134

Zampieri E, Murat C, Cagnasso M, Bonfante P, Mello A (2010) Soil analysis reveals the presence of an extended mycelial network in a Tuber magnatum truffle-ground. FEMS Microbiol Ecol 71:43-49

Zawirska-Wojtasiak R (2004) Optical purity of (R)-(-)-1octen-3-ol in the aroma of various species of edible mushrooms. Food Chem 86:113-118

Zhang HH, Tang M, Chen H, Zheng CL (2010) Effects of inoculation with ectomycorrhizal fungi on microbial biomass and bacterial functional diversity in the rhizosphere of Pinus tabulaeformis seedlings. Eur J Soil Biol 46:55-61

Zhang A, Xiao N, He P, Sun P (2011) Chemical analysis and antioxidant activity in vitro of polysaccharides extracted from Boletus edulis. Int J Biol Macromol 49:1092-1095

Zheng CJ, Yoo JS, Lee TG, Cho HY, Kim YH, Kim WG (2005) Fatty acid synthesis is a target for antibacterial activity of unsaturated fatty acids. FEBS Lett 579:5157-5162 